DANMARKS GEOLOGISKE UNDERS $\varnothing$ GELSE

IV. RAKKE. BD. 4. NR. 1

GEOLOGICAL SURVEY OF DENMARK. IV. SERIES. VOL. 4 . NO. 1

\title{
Silicone Oil as a Mounting Medium for Pollen Grains
}

by

Svend Th. Andersen

Dansk sammendrag

I kommission hos

C. A. REITZELS FORLAG (J $\oslash R G E N$ SANDAL)

KøBENHAVN 1960 


\title{
DANMARKS GEOLOGISKE UNDERSØGELSE
}

IV. RæKKE. B D. 4. NR. 1

Geological Survey of Denmark. IV. Series. Vol. 4. No. 1.

\section{Silicone Oil as a Mounting Medium for Pollen Grains}

\author{
by
}

Svend Th. Andersen

Dansk sammendrag

C. A. REITZELS FORLAG (JØRGEN SANDAL) 


\section{GONTENTS}

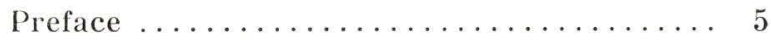

Introduction $\ldots \ldots \ldots \ldots \ldots \ldots \ldots \ldots \ldots$

Qualities of mounting media ........... 10

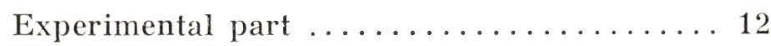

Stability of size of acetolyzed modern Corylus

avellana pollen in various mounting media 12

Size of fossil Corylus avellana pollen (post-

glacial) in silicone oil ............. 13

Mounting procedure .............. 15

Summary .................... 18

Literature $\ldots \ldots \ldots \ldots \ldots \ldots \ldots \ldots \ldots$

Dansk sammendrag ............... 20

Tables $3-8 \ldots \ldots \ldots \ldots \ldots \ldots \ldots \ldots \ldots \ldots \ldots$ 


\section{Preface}

The present work was carried out at the Paleobotanical Laboratory of the Geological Survey of Denmark and represents the results of several years' search for a satisfactory mounting medium for acetolyzed pollen grains. The various steps of progress have been discussed continuously with colleagues there, above all with Dr. Johs. Iversen, who has strongly encouraged the work, and with colleagues at the National MUseum. Mr. B. Brorson Christensen has given substantial help, and Mrs. Kathryn H. Clisby, Oberlin, Ohio, has contributed too. The problems were discussed keenly with Professor A. Orville Dahl during his stay here. As he had similar objectives for application on fresh pollen, part of our search was carried out in common. The most valuable contribution and help was given by Mr. Bent Andersen, civil engineer, Aarhus, who suggested the two most promising media, tricaproïn and silicone oil. 


\section{Introduction}

With the refinement of pollen analysis and with the need for more exact identifications, a number of special problems present themselves. Detailed comparative morphology becomes increasingly important and with it the requirements as to the properties of the embedding medium increase.

The problems of species identifications, especially, call for a comparison of the "coarseness" of morphological details. Hence it becomes desirable that the pollen exines to be studied are found in comparable states of expansion. Chemical treatments of various kinds are well known to modify the size of pollen grains greatly, but as will be shown below the qualities of the embedding media influence their immediate state too.

For the study of diagnostically valuable characteristics such as pore configuration and sculpture of intercolpia and polar areas (cp. IVERSEN and Troels-Smith 1950, F ÆGri and Iversen 1950, FæGri 1956) it often is desirable that the individual pollen grains can be turned. This is also a necessity for measuring the many quantities defined by Iversen and Troels-Smith (l. c.). In cases of rare fossil pollen finds one usually will want to retain the grains in such a state that they are available for later re-consideration according to the principles outlined above.

For a long time students of fossil and recent acetolyzed pollen exines have been satisfied with the results obtainable with material mounted in glycerin and glycerin-jelly. However, especially the article of CHRISTENSEN (1954) has called attention to the insufficiencies of these media. As Christensen (l. c.) pointed out, glycerin in a pure state has an unfavourable refractive index in relation to that of pollen exines. As glycerin is hygroscopic it almost inevitably contains water, which renders the refractive index somewhat more favourable. On the other hand pollen exines have a tendency to swell in these media, according to CHristenSEN (l. c.) probably due to absorption of water.

At the Paleobotanical Laboratory of the Geological Survey of Denmark acetolyzed modern reference preparations were mounted in glycerinjelly. For control of size changes modern pollen of Corylus avellana (Denmark, various sources) was mixed into the material prior to chemical treatment (cp. Chusstensen 1946). In this way it is possible, by measurement of the Corylus pollen, to get an idea of the constancy of size in the preparations. The results of such measurements carried out on slides prepared 1946-1955 are shown in table 1. 
Table 1. Corylus avellana, modern. $\mathrm{KOH}$, acetolysis, glycerin-jelly. (measured January 1959). " Slides received as exchange from the National Museum, Dept. of Natural Science. N: total of pollen measured.

$\mathrm{M}$ : mean size. $\sigma$ : standard deviation.

\begin{tabular}{|c|c|c|c|c|}
\hline Ref.no. & Year prepared & $\mathrm{N}$ & $\begin{array}{c}\mathrm{M} \\
\text { microns }\end{array}$ & $\begin{array}{c}\sigma \\
\text { microns }\end{array}$ \\
\hline $1163^{*}$ & $1948 \ldots$ & 100 & 31,87 & $\pm 1,51$ \\
\hline $661^{*}$ & $1946 \ldots$ & 100 & 36,42 & $\pm 1,51$ \\
\hline 1201 & $1951 \ldots \ldots \ldots \ldots \ldots$ & 100 & 37,49 & $\pm 2,08$ \\
\hline 539 & $1955 \ldots \ldots \ldots \ldots \ldots$ & 100 & 40,92 & $\pm 2,15$ \\
\hline $2042^{5}$ & $1952 \ldots \ldots \ldots \ldots \ldots$ & 100 & 43,19 & $\pm 2,18$ \\
\hline 1101 & $1950 \ldots \ldots \ldots \ldots$ & 100 & 44,64 & $\pm 2,24$ \\
\hline
\end{tabular}

According to Christensen (1. c.) the average size of modern Corylus avellana pollen in freshly made slides varies only slightly. For acetolyzed Corylus avellana pollen (preliminary boiling with potassium hydroxyde) mounted in glycerin and measured immediately after mounting CHRISTENSEN (1. c.) gives the mean size 31.5 microns (averaged from two collections). From table 1 it may be seen that the Corylus pollen varies extremely in the slides measured. It appears that size increase has taken place during storage of the slides, and, what is worse, to an unpredictable degree. Most people working with reference collections probably have made the observation that the pollen grains in some slide or other are "swollen" or "pale"1). It seems needless to point out that such a heterogeneous character of the reference material represents an obstacle for detailed work of the kind described above. Working with our reference collection we have, of course, been aware of the difficulty. The slides usually were studied shortly after the preparation before extensive swelling had taken place. But it seems clear that more homogeneous and durable slides would be of great advantage for future work.

Fossil material usually was mounted in glycerin. Christensen (1946) showed that the mean sizes of fossil pollen treated according to standard preparation methods and mounted in glycerin differ substantially from the mean sizes for modern pollen (cp. also p. 13 and fig. 2).

The glycerin slides with fossil material usually are not sealed making it possible to roll individual pollen grains by gentle pushing of the cover slip. Left unsealed the glycerin evaporates in a few years. Swelling of the pollen grains often takes place as well although not as pronouncedly as in the case of the modern reference slides. At the National Museum, Dept. of Natural Science, Corylus pollen is measured in fossil prepara-

Table 2. Corylus avellana, fossil (postglacial). Glycerin.

$\begin{array}{llcccc}\text { Ref.no. } & \text { Treatment } & \begin{array}{c}\text { Year } \\ \text { measured }\end{array} & \text { N } & \begin{array}{c}\text { M } \\ \text { microns }\end{array} & \begin{array}{c}\sigma \\ \text { microns } \\ \pm 2,75\end{array} \\ \text { HP 592 } & \text { KOH, HF, acetolysis . . } & 1952 & 104 & 29,98 & \pm 2,91 \\ & & 1959 & 100 & 28,15 & \pm 1,91 \\ \text { H 1157 } & \text { KOH, acetolysis . ...... } & 1954 & 100 & 34,93 & \pm 1,87 \\ & & 1959 & 69 & 34,31 & \pm 1,98 \\ \text { H 4092 } & \text { KOH, acetolysis ....... } & 1950 & 107 & 33,47 & \pm 3,17 \\ & & 1959 & 100 & 37,54 & \pm 3,92\end{array}$

1) Similar observations were stated by Erdtman and Praglowski (1959). 
tions, whenever possible. In order to control size changes, Corylus pollen in some of these preparations was re-measured. The results are shown in table 2. ${ }^{1}$.

In the samples HP 592 and H 1157 the fossil material was measured in sealed slides. Here no swelling has taken place probably due to prevention of absorption of water from the air by the sealing. In some of the preparations a few swollen grains were observed along the edges of the cover slips. In H 4092 material kept in a stoppered vial was measured in 1959. Here the Corylus pollen had become rather heterogeneous. In 1950 the size range was $25.0-36.9$ microns, in 1959 it was 27.6-50.4 microns and the average size had increased by 4.07 microns (standard error of the difference \pm 0.50 microns).

It appears that fossil pollen mounted in glycerin and kept in sealed slides is unlikely to swell appreciably. On the other hand, details of rare pollen types cannot be re-examined satisfactorily, as the grains cannot be turned. Unsealed glycerin slides are unlikely to keep for more than a few years.

The undesirable properties of glycerin or glycerin-jelly as mounting media for acetolyzed modern and fossil pollen grains may be summarized as follows.

1) Refractive index, in water-free state, too high.

2) In modern reference slides swelling of the pollen grains may take place to an unpredictable degree.

3 ) When mounted in glycerin the size of fossil pollen is highly variable especially according to chemical treatment and rather different from that of acetolyzed modern pollen.

4) Fossil slides are durable only if sealed.

1) The material was kindly placed at disposal by J. Troels-Smith. 


\section{Qualities of Mounting Media}

For the reasons outlined above one of our major concerns has been to find a mounting medium, which would meet all requirements as to optical as well as physical and chemical properties. Ideally the same medium should be used for fossil and modern reference material. In the following the main requirements according to our experience and the ability of a number of media available to us to fulfill these will be discussed.

1. Refractive index. For good contrast the r.i. should differ substantially from that of the pollen (cp. the discussion by CHRISTENSEN 1954). A r.i. higher than that of the exines results in a rather confusing image (cp. Christensen 1. c., all available media with r. i. higher than 1.60 are solid). For ordinary and phase contrast microscopy of pollen exines r.i. 1.40-1.46 have proved favourable. R.i. at $1.47-1.50$ give too little contrast and the results especially with phase contrast are disappointing.

2. Viscosity. For detailed study and measurements of rare and critical pollen finds the possibility of turning the individual grains is desirable (cp. above). Moreover turning of the individual grains may facilitate the identification of damaged grains of more ordinary types. In size-statistical studies this possibility is desirable too, as in that way all undamaged grains can be brought into the position required for carrying out the measurements. In unsealed slides turning of the grains is possible by gentle pushing of the cover slip provided the mounting medium posesses a certain viscosity and the amount of liquid is not excessive. As it often is necessary to preserve the pollen finds for later re-consideration the viscosity of the medium must remain unchanged.

3. Volatility. As the fossil slides should be preserved without sealing the ideal medium must be non-volatile.

4. Inertness. The mounting medium should be chemically stable. After mounting it should affect the size of the pollen exines as little as possible. This quality can be tested only by experience. Experiments concerning the stability of pollen grains preserved in the mounting media discussed here are described in the following chapter. The medium should not absorb water. 
5. Availability. The medium should be commercially available in a high grade of purity, preferably of known chemical composition or affinity.

To sum up the ideal mounting medium for fossil pollen and for recent acetolyzed reference material should have the following properties.

1) Refractive index 1.40-1.46.

2) Viscosity rather high and constant.

3) Non-volatile.

4) Inert and non-hygroscopic.

5) Commercially available.

In addition it will be useful if the sizes of pollen grains in fossil and modern preparations differ only slightly.

The following mounting media available to us have been studied in reference to their ability to meet the above requirements. They will be mentioned in order of decreasing refractive indices (at $20^{\circ} \mathrm{C}$ if not otherwise stated).

Tanglefoot medium no. 6. (r.i. ca. 1.49). This medium meets the requirements $2-4$ and partly 5 . The r.i. is too high and optical results especially with phase contrast are unfavourable (available from the Tanglefoot Company, Grand Rapids, Michigan, U.S.A.).

A esculus gum (r.i. 1.49). This medium was proposed by ChristenSEN (1954). It meets requirements $2-4$. The r.i. is too high.

Paraffin oil (r.i. 1.48). High viscosity grades meet requirements $2-5$, but r.i. is too high.

Oleum papaveri (r.i. 1.474). Cp. Christensen (l.c.). Meets requirements $3-5$, but hardening is inevitable. Other natural oils of "non drying" type and with similar r.i. such as almond oil, olive oil, peanut oil and sperm oil (r.i. 1.47-1.45) also are chemically unstable and likely to break down into lower compounds.

Tricaproïn (trihexanoïn, r.i. 1.442). Meets requirements 1 and $3-5$. The viscosity is too low. Available from Eastman Organic Chemicals Department, Rochester 3, N.Y., U.S.A.

Tributyrin (r.i. 1.436). Meets requirements 1 and 3-5. The viscosity is too low. Available like tricaproïn.

Silicone oil. Synthetic silicone oils of various viscosity degrees have been available to us (produced by Wacker-Chemie G.m.b.H., München, Germany, viscosity indices AK 350-10.000). The r.i. increases slightly with increasing viscosity varying between $1.403-1.404$ (at $25^{\circ} \mathrm{C}$ ). The optical qualities have proved excellent. Viscosity index AK 2000 has proved extremely favourable for turning of the pollen grains. The silicone oils are known for their chemical inertness, water repellent properties and stability of viscosity within time and a wide temperature range. The chemical composition of silicone oils is known, and they are commercially available in a highly pure state. Silicone oil, accordingly, looks promising as a mounting medium for acetolyzed pollen grains. Below further experiments are reported in detail. 


\section{Experimental Part}

\section{Stability of size of modern, acetolyzed Corylus avellana pollen in various mounting media.}

In the following eperiments concerning the reaction of Corylus avellana pollen to embedding and preservation in various mounting media will be discussed.

For all measurements the same source (Hareskoven, Zealand, ca. 70 individuals collected 1957, air dry) was used. The size class was 1.20 microns and in each case 100 pollen grains were measured. The standard deviations $(\sigma)$ of all means reported in this and the following chapters vary 1.06-2.21 microns (cp. tables 3-12). In general all differences of means smaller than 0.30 microns will be insignificant, and all differences larger than 0.62 microns significant for $\mathrm{P}=0.05$.

Fig. 1 (cp.table 3) illustrates the mean sizes of modern pollen mounted in glycerin and some of the media described above (oleum papaveri, Aesculus gum, tricapoïn, Tanglefoot no.6, silicone oil AK 2000)

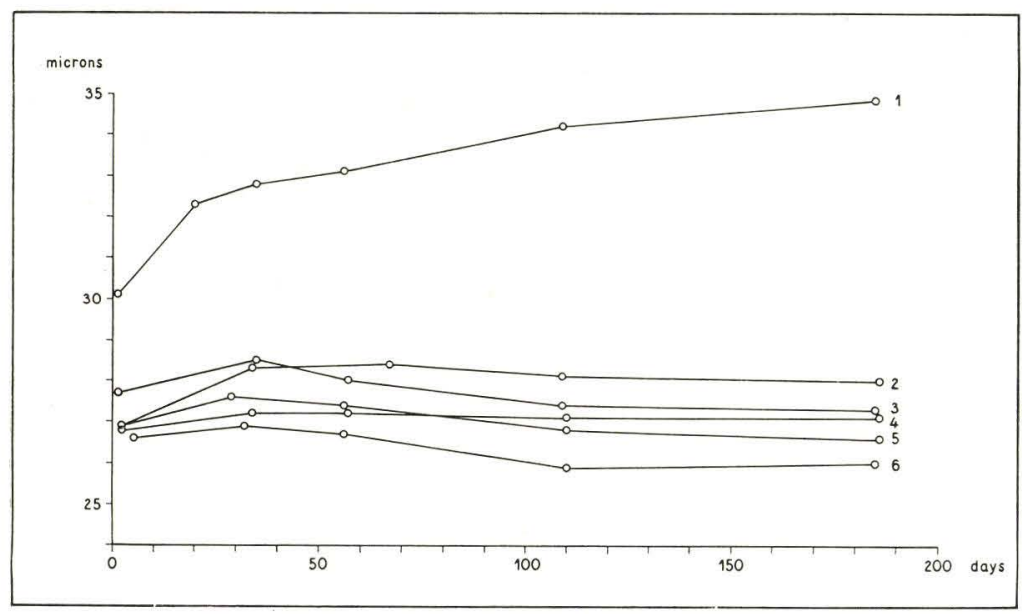

Fig. 1. Corylus avellana, modern (treated with $\mathrm{KOH}$ and acetolysis). Changes of mean size with storage in various mounting media (cp. tables 3-4). 1: Glycerin. 2: Oleum papaveri. 3: Aesculus gum. 4: Tanglefoot no. 6. 5: Tricaproïn. 6: Silicone oil AK 2000. 
and their variation with storage. One large portion was prepared (boiling in $\mathrm{KOH}$, acetolysis). Water was removed with acetone. The glycerin mount was made from acetone directly, for the other media benzene was used as solvent. The slides were made after evaporation of the solvent. They were kept unsealed and the same slides were re-measured. From fig. 1 it may be seen that the mean size of the pollen grains mounted in glycerin increases rapidly (initial size 30.14 microns, after 20 days 32.29 microns). After 185 days the mean size had increased to 34.86 microns, an increase of 4.72 microns or $16 \%$ of the original size. In the other media the initial mean sizes vary between 27.65 microns (Aesculus gum) and 26.64 microns (silicone oil). By storage in these media the pollen grains behave in a peculiar, but as it seems similar way (significance tests for differences of means are shown in table 4). Within 30 days the mean sizes increase slightly, whereupon they decrease somewhat. After 110 days the mean sizes remain practically unchanged. For the silicone oil mount (initial size 26.64 microns) the mean size after 110 days was 25.94 microns, after 185 days 26.03 microns ${ }^{1}$ ).

The experiment illustrated in fig. 1 (cp.tables 3-4) thus shows that the size of modern acetolyzed Corylus pollen remains rather unchanged by storage for at least 6 months in the media mentioned except for glycerin and oleum papaveri. Within 110 days slight size changes may take place. The probable reasons for these have not been studied.

\section{Size of fossil Corylus avellana pollen (postglacial) in silicone oil.}

Fig. 2 shows a comparison of the mean size of fossil and modern pollen of Corylus avellana mounted in glycerin and in silicone oil.

It may be seen that the mean sizes of the pollen mounted in silicone oil vary much less than those from glycerin slides (measured immediately after chemical treatment). This, of course, is of advantage for morphological comparison of pollen grains.

The mean sizes of Corylus pollen from the fossil samples mounted in silicone oil differ slightly. Relation of mean size to sediment type is illustrated in fig. 3. It appears that the pollen grains are largest in the Sphagnum-Calluna peat and in the humus sample. The latter sediment, from Draved, S. Jutland, is strongly acid $(\mathrm{pH} 4)$. A certain correlation between acidity of the sediment and pollen size is suggested. In the most acid sediments the size of the acetolyzed pollen grains is similar to the modern material. A similar result was reached by Firbas and Firbas (1935) for KOH-treated material mounted in glycerin.

Fig. 4 (cp. table 6) illustrates the variation with time of the mean size of Corylus pollen from three of the sediment samples just mentioned.

1) Measured after 366 days the mean size was $\mathbf{2 6 . 4 1}$ microns (cp.table 3 ). 


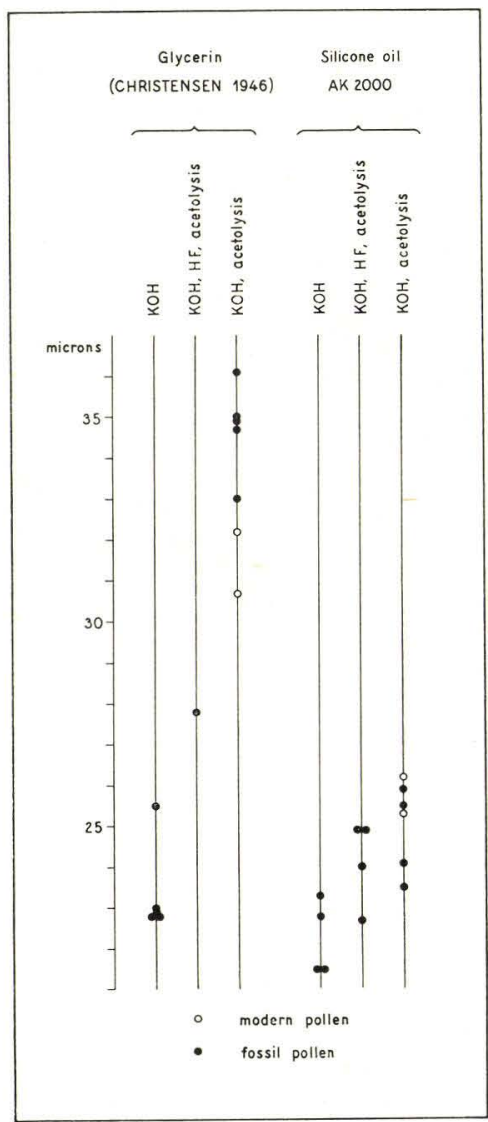

Fig. 2. Corylus avellana, fossil (postglacial) and modern. Mean size in glycerin and silicone oil after various chemical treatments (cp. Christensen 1946 and table 5).

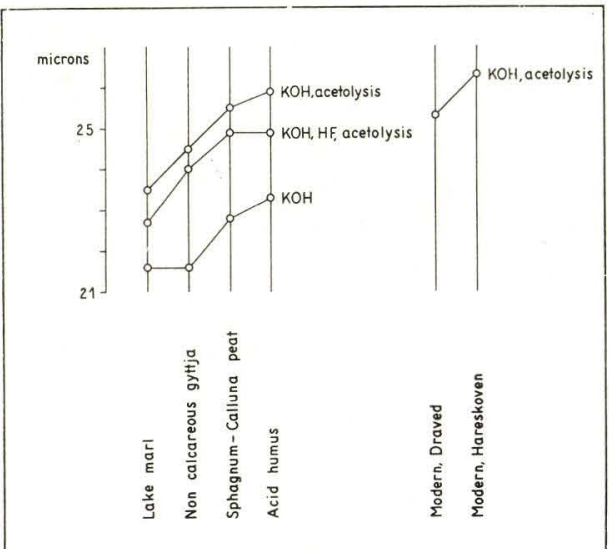

Fig. 3. Corylus avellana, fossil (postglacial), from various sediment types, and modern. Mean size in silicone oil after various chemical treatments (cp. table 5).

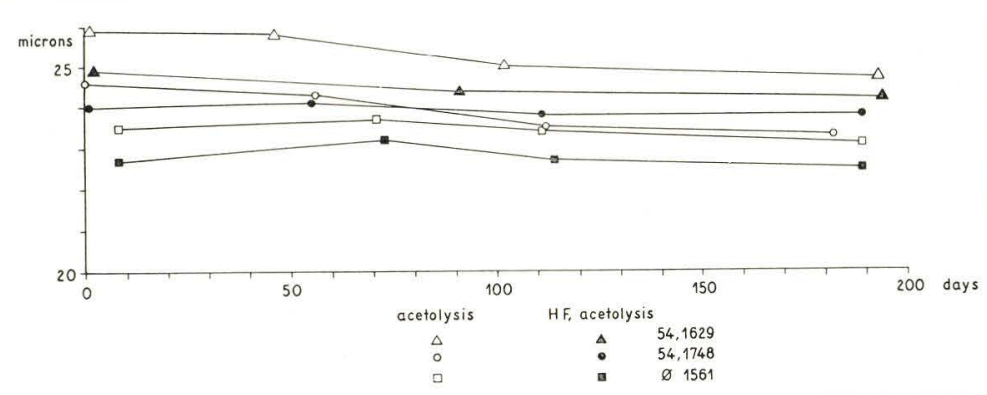

Fig. 4. Corylus avellana, fossil (postglacial), from various samples, acetolyzed with or without preliminary treatment with HF. Changes of mean size with storage in silicone oil (cp. tables 6-7). 
Significance tests for size changes are shown in table 7. It may be seen that slight size changes may take place especially within the first 100 days, but after that date and wihtin 200 days the size changes are insignificant ${ }^{1}$ ).

The total size changes seem to depend to a certain degree on absolute size of the pollen, for the HF-treated samples they are practically insignificant. For samples acetolyzed without HF-treatment size decrease of about 1 micron may take place.

\section{Mounting procedure.}

The effect of various de-hydrants and solvents on modern Corylus avellana pollen is shown in fig. 5 ( $\mathrm{cp}$. table 8 ). One large portion of air dry Corylus pollen (Hareskoven, N. Sealand) was treated chemically

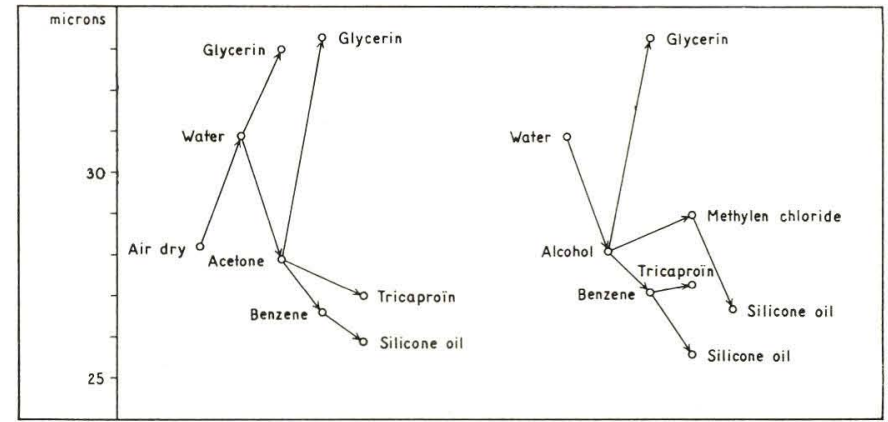

Fig. 5. Corylus avellana, modern. Mean size in air dry state and after chemical treatment and transferal to various solvents and mounting media (cp. table 8).

( $\mathrm{KOH}$, acetolysis). After washing with water the sample was brought into the various chemicals and measured in the order shown in fig. 5 .

From the figure it may appear that the size of acetolyzed pollen exines is greatly variable indeed, change of size taking place each time the pollen grains are brought into another liquid. The reasons are unknown, and have not been explored.

Whenever pollen sizes from different preparations are to be compared it seems important that they should have identical chemical "history". Boiling with $\mathrm{KOH}$ and acetolysis produces an increase in size of about 3 microns. Embedding in glycerin causes further swelling. Removal of water by acetone on the other hand makes the size similar to the original

1) The samples with the largest and the smallest pollen $(54.1629$, acetolyzed and $\emptyset 1561$, $\mathrm{HF}$, acetolyzed) were re-measured after 366 and 372 days. No significant changes had taken place (cp. tables 6-7). 
one for untreated air dry pollen. Passage into benzene and silicone oil cause progressive size decrease. In a part of the sample water was removed with alcohol. Here similar size changes took place.

It has proved that acetone may produce a precipitate, when used for preparation of modern pollen, and alcohol may be preferred for removal of water.

For pollen grains mounted in silicone oil staining is no necessity. Staining with fuchsin is possible, but the benzene may bleach the stain somewhat. The results vary considerably in fossil samples.

The procedure for mounting acetolyzed fossil or modern pollen in silicone oil may be summarized as follows,

1) wash with water,

2) wash with a few drops of water and $96 \%$ alcohol,

3) wash with $99,9 \%$ alcohol, stain with fuchsin if desired,

4) wash with benzene,

5) add about $1 \mathrm{ml}$ benzene, transfer to small vial, add silicone oil, leave for evaporation for about 24 hours. The vials may be kept for future use.

6) add the amount of silicone oil needed for optimal concentration of the pollen. In making the slides the smallest possible amount of liquid should be used. The droplet spreads under the cover slip very slowly (5-10 minutes). For fossil slides small cover slips $(18 \times \mathbf{1 8}$ $\mathrm{mm})$ are recommendable. Modern slides may be sealed with nail polish.

Modern pollen grains mounted in silicone oil, according to our experience, are very uniform, and, accordingly, favourable for comparative morphological studies, making of keys etc. Because of the low refractive index contrasts become emphasized. In this way delicate sculpture patterns stand out and may be studied with advantage. For objectives with high numerical aperture the low refractive index may cause a slight decrease of resolution, but in our experience this is compensated for by the increase of contrast ${ }^{1}$.

Because of the compactness of the pollen grains diffraction lines may appear around the outline of the grains when seen in optical section (they are seen also in Aesculus gum, Tanglefoot no. 6, oleum papaveri, tricaproïn). They may be reduced by opening of the aperture diaphragm of the microscope somewhat more than usual. Opening of this diaphragm causes loss of contrast. In silicone oil, however, the optical picture is so rich in contrast that this is immaterial. For phase contrast optics silicone oil is favourable.

In slides of fossil material mounted in silicone oil the richness of contrast renders the optical results favourable. With good dry objectives

1) The decrease of resolution is small and by far not comparable to e.g. the loss of resolution caused by omitting the use of a substage immersion condensor. 
(numerical aperture 0.70-0.95) sculpture details become very distinct. This, of course, is of advantage for routine work. Staining is of less importance and should not be used excessively. Because of the high viscosity any problematic pollen grain may be rolled by gentle pushing of the cover slip. Individual pollen grains of special interest may be re-found without difficulty provided that the slides are thin and the pollen not too concentrated, and if handled with some care. For measurements the pollen grains can be brought into the positions required with ease. For unsealed slides anisol is convenient as immersion liquid, because of its volatility. 


\section{Summary}

The observations as to the size stability of pollen grains when preserved in silicone oil have been carried out for a rather short time only. So far, however, the results look promising. In summary the qualities of silicone oil as mounting medium for acetolyzed pollen may be stated as follows,

1) Refractive index is favourable for ordinary microscopy as well as for phase contrast.

2) Viscosity index AK 2000 is favourable for the turning of individual pollen grains into any position desired.

3) Chemically silicone oil is very stable. No change of viscosity or other physical properties is likely to take place.

4) Measurements indicate that in modern, acetolyzed pollen only slight size changes take place within one year (cp. fig. 1 and tables $3-4$ ).

5) The size of fossil pollen treated chemically by standard methods does not differ greatly from that of modern pollen treated with $\mathrm{KOH}$ and acetolysis (cp. fig. 2). In the samples studied the average size of fossil pollen was largest in acid sediments (cp. fig. 3). Measurements indicate that in acetolyzed fossil pollen size changes are rather small. For samples treated with $\mathrm{HF}$ prior to acetolysis size changes are less than 1 micron (cp. fig. 5 and tables 6-7).

6) Mounting procedure is described in detail (p. 16). 


\section{Literature}

Christensen, B. Brorson, 1946: Measurement as a means of identifying fossil pollen. Danmarks Geologiske Undersøgelse. IV. Række. Bd. 3. Nr. 2. København.

- 1954: New mounting media for pollen grains. Danmarks Geologiske Undersøgelse. II. Række. Nr. 80, p. 7-11. København.

Erdtman, G. and Praglowski, J. R., 1959: On the swelling of pollen grains in glycerine jelly. Botaniska Notiser. Vol. 112, p. 175-176. Lund.

Firbas, F. and Firbas, I., 1935: Zur Frage der grössenstatistischen Pollendiagnosen. Beihefte zum Botanischen Centralblatt. Band LIV. Abteilung B. Dresden.

FæGRI, K., 1956: Palynological studies in NW European Papilionaceae. The University of Bergen. Botanical Museum. Mimeographed.

- and Iversen, Johs., 1950: Text-book of modern pollen analysis. København.

Iversen, J. and Troels-Smith, J., 1950: Pollenmorphologische Lefinitionen und Typen. Danmarks Geologiske Undersøgelse. IV. Række. Bd. 3. Nr. 8. København. 


\section{Dansk sammendrag}

Med intensiveringen af den pollenanalytiske metode vokser $\varnothing$ nsket om mere eksakte bestemmelser af fossilt pollen, især artsbestemmelser, som i h $\varnothing$ j grad afhænger af en sammenligning af morfologiske detailler. Herved vokser kravene til indlejningsmediet, idet pollenkornene i forskellige præparater må være og kunne forblive så ensartede som muligt. Ligeledes må de fossile pollenkorn kunne vendes, både for studium af detailler og for målinger, og for sjældne fossilfund gælder det, at man ofte vil $\emptyset$ nske at kunne studere dem igen senere under de samme betingelser. Glycerin og glycerin-gelatine er hidtil blevet brugt i udstrakt grad. De har imidlertid flere utilfredsstillende egenskaber, og det har derfor været af væsentlig betydning at finde et medium, der bedre dækker de for $\varnothing$ gede krav.

De nnskelige egenskaber kan sammenfattes således: 1) Brydningsindex skal være 1.40-1.46. 2) Viskositeten skal være ret høj og må ikke ændres. 3) Mediet må ikke kunne fordampe. 4) Mediet skal være kemisk inaktivt og må ikke suge vand, og pollenkornenes størrelse ikke ændres ved opbevaring. 5) Det må være tilgængeligt i handelen. Forskellige medier (se s. 11) er blevet undersøgt for disse egenskaber. Deres evne til at bevare den oprindelige størrelse af recente pollenkorn er unders $\emptyset \mathrm{gt}$ ved målinger (se fig. 1). Det har vist sig, at siliconolie opfylder de stillede krav bedst. Dets indvirkning på st $\varnothing$ rrelsen af pollenet i fossile prøver er belyst i fig. 2-4. Fremgangsmåden ved overførsel af acetolyseret recent og fossilt pollen til siliconolie er vist på s. 16. 


\section{Tables $3-8$}

Table 3. Corylus avellana, modern (Hareskoven, N. Zealand). KOH, acetolysis. Dehydration: acetone. Solvent (for media other than glycerin): Benzene. M: mean size. $\sigma$ : standard deviation.

\begin{tabular}{|c|c|c|c|}
\hline Medium & $\begin{array}{l}\text { Storage period } \\
\text { days }\end{array}$ & $\begin{array}{c}\text { M } \\
\text { microns }\end{array}$ & $\begin{array}{c}\sigma \\
\text { microns }\end{array}$ \\
\hline \multirow[t]{6}{*}{ Glycerin $\ldots \ldots \ldots \ldots \ldots \ldots \ldots \ldots$} & 1 & 30,14 & $\pm 1,85$ \\
\hline & 20 & 32,29 & $\pm 1,74$ \\
\hline & 35 & 32,76 & $\pm 1,98$ \\
\hline & 56 & 33,11 & $\pm 2,05$ \\
\hline & 109 & 34,15 & $\pm 1,99$ \\
\hline & 185 & 34,86 & $\pm 2,21$ \\
\hline \multirow[t]{5}{*}{ Aesculus gum } & 1 & 27,65 & $\pm 1,45$ \\
\hline & 35 & 28,46 & $\pm 1,34$ \\
\hline & 57 & 27,97 & $\pm 1,45$ \\
\hline & 109 & 27,40 & $\pm 1,43$ \\
\hline & 185 & 27,25 & $\pm 1,43$ \\
\hline \multirow{5}{*}{ Oleum papaveri $\ldots \ldots \ldots \ldots \ldots \ldots$} & 2 & 26,89 & $\pm 1,45$ \\
\hline & 34 & 28,32 & $\pm 1,52$ \\
\hline & 57 & 28,36 & $\pm 1,38$ \\
\hline & 109 & 28,08 & $\pm 1,44$ \\
\hline & 186 & 28,01 & $\pm 1,66$ \\
\hline \multirow[t]{5}{*}{ Tricaproïn ................. } & 2 & 26,92 & $\pm 1,53$ \\
\hline & 29 & 27,58 & $\pm 1,60$ \\
\hline & 56 & 27,38 & $\pm 1,38$ \\
\hline & 110 & 26,82 & $\pm 1,51$ \\
\hline & 187 & 26,63 & $\pm 1,39$ \\
\hline \multirow{5}{*}{ Tanglefoot no. $6 \ldots \ldots \ldots \ldots \ldots$} & 2 & 26,84 & $\pm 1,36$ \\
\hline & 34 & 27,17 & $\pm 1,38$ \\
\hline & 57 & 27,23 & $\pm 1,38$ \\
\hline & 110 & 27,08 & $\pm 1,32$ \\
\hline & 186 & 27,12 & $\pm 1,38$ \\
\hline \multirow{6}{*}{ Silicone oil AK 2000} & 5 & 26,64 & $\pm 1,34$ \\
\hline & 32 & 26,86 & $\pm 1,24$ \\
\hline & 56 & 26,70 & $\pm 1,36$ \\
\hline & 110 & 25,94 & $+1,43$ \\
\hline & 185 & 26,03 & $\pm 1,34$ \\
\hline & 366 & 26,41 & $\pm 1,31$ \\
\hline
\end{tabular}


Table 4. Significance tests for size changes according to table 3 .

\begin{tabular}{|c|c|c|c|c|}
\hline Medium & \multicolumn{2}{|c|}{$\begin{array}{c}\text { Difference of means, } \\
\text { microns }\end{array}$} & $\begin{array}{l}\text { Smallest significant } \\
\text { difference for P } 0,05 \text {, } \\
\text { microns }\end{array}$ & $\begin{array}{l}\text { Signif } \\
\text { canc }\end{array}$ \\
\hline \multirow[t]{4}{*}{ Aesculus gum . . . . . . . } & $a-b$ & $+0,81$ & $\pm 0,39$ & $x$ \\
\hline & $b-d$ & $-0,49$ & $\pm 0,39$ & \\
\hline & $a-d$ & $-0,25$ & $\pm 0,41$ & \\
\hline & $\mathrm{d}-\mathrm{e}$ & $-0,15$ & $\pm 0,40$ & \\
\hline \multirow[t]{4}{*}{ Oleum papaveri ...... } & $a-b$ & $+1,43$ & $\pm 0,42$ & \\
\hline & $\mathrm{b}-\mathrm{d}$ & $-0,24$ & $\pm 0,42$ & \\
\hline & $a-d$ & $+1,19$ & $\pm 0,41$ & $x$ \\
\hline & $\mathrm{d}-\mathrm{e}$ & $-0,07$ & $\pm 0,44$ & \\
\hline \multirow[t]{4}{*}{ Tricaproïn . . . . . . . } & $a-b$ & $+0,66$ & 0,44 & $x$ \\
\hline & $\mathrm{b}-\mathrm{d}$ & $-0,76$ & $\pm 0,44$ & \\
\hline & $a-d$ & $-0,10$ & $\pm 0,43$ & \\
\hline & d-e & $-0,20$ & $\pm 0,41$ & \\
\hline \multirow[t]{4}{*}{ Tanglefoot no. $6 \ldots \ldots$} & $a-b$ & $+0,33$ & $\pm 0,39$ & \\
\hline & $\mathrm{b}-\mathrm{d}$ & $-0,09$ & $\pm 0,38$ & \\
\hline & $a-d$ & $+0,24$ & $\pm 0,38$ & \\
\hline & $\mathrm{d}-\mathrm{e}$ & $+0,04$ & $\pm 0,38$ & \\
\hline \multirow[t]{5}{*}{ Silicone oil $\mathrm{AK} / 2000 \ldots$} & $a-b$ & $+0,22$ & $\pm 0,36$ & \\
\hline & $\mathrm{b}-\mathrm{d}$ & $-0,92$ & $=0,38$ & $\times$ \\
\hline & $a-d$ & $-0,70$ & $\pm 0,39$ & 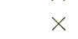 \\
\hline & $\mathrm{d}-\mathrm{f}$ & $+0,47$ & $\pm 0,38$ & $x$ \\
\hline & $a-f$ & $-0,23$ & $\pm 0,38$ & \\
\hline
\end{tabular}

Talle 5. Corylus azellana, fossil (postglacial) and modern. Silicone oil AK 2000 (acetone, benzene).

\begin{tabular}{|c|c|c|c|c|c|c|}
\hline \multirow[t]{2}{*}{ Ref.no. } & \multirow[t]{2}{*}{ Source } & \multicolumn{3}{|c|}{ Treatment } & M & \multirow[b]{2}{*}{ 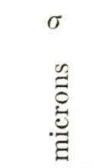 } \\
\hline & & $\stackrel{1}{0}$ & 至 & $\frac{n}{\frac{n}{0}}$ & $\begin{array}{l}\stackrel{0}{\Xi} \\
\vdots \\
\vdots \\
\Xi\end{array}$ & \\
\hline 54.1629 & Postglacial, acid humus & + & & & 23,29 & $\pm 1,28$ \\
\hline & & + & + & + & 24,89 & $\pm 1,58$ \\
\hline & & + & & + & 25,88 & $\pm 1,62$ \\
\hline .551 & Postglacial, Sphagnum-Calluna peat ... & + & & & 22,81 & $\pm 1,20$ \\
\hline & & + & + & + & 24,86 & $\pm 1,28$ \\
\hline & & + & & + & 25,52 & $\pm 1,62$ \\
\hline 54.1748 & Postglacial, non calcareous gyttja ..... & + & & & 21,55 & $\pm 1,17$ \\
\hline & & + & + & + & 24,02 & $\pm 1,40$ \\
\hline & & + & & + & 24,59 & $\pm 1,85$ \\
\hline Ø 1561 & Postglacial, lake marl . . . . . . . . . . & + & & & 21,62 & $\pm 1,21$ \\
\hline & & + & + & + & 22,69 & $\pm 1,27$ \\
\hline & & + & & + & 23,48 & $\pm 1,27$ \\
\hline & Modern, Draved S Jutland. . . . . . . . . & + & & + & 25,30 & $\pm 1,14$ \\
\hline & Modern, Hareskoven N Zealand ...... & + & & + & 26,26 & $\pm 1,35$ \\
\hline
\end{tabular}


Table 6. Corylus avellana pollen, fossil (postglacial). Silicone oil AK 2000 (acetone, benzene).

\begin{tabular}{|c|c|c|c|c|}
\hline Ref.no. & Treatment & $\begin{array}{l}\text { torage period } \\
\text { days }\end{array}$ & $\begin{array}{c}\mathrm{M} \\
\text { microns }\end{array}$ & $\begin{array}{c}\sigma \\
\text { microns }\end{array}$ \\
\hline \multirow[t]{8}{*}{54.1629} & $\mathrm{KOH}$, acetolysis . . . . . . & 1 & 25,88 & $\pm 1,62$ \\
\hline & & 46 & 25,81 & $\pm 1,50$ \\
\hline & & 102 & 24,96 & $\pm 1,67$ \\
\hline & & 193 & 24,66 & $\pm 1,52$ \\
\hline & & 366 & 24,96 & $\pm 1,65$ \\
\hline & $\mathrm{KOH}, \mathrm{HF}$, acetolysis. . & 2 & 24,89 & $\pm 1,58$ \\
\hline & & 92 & 24,40 & $\pm 1,26$ \\
\hline & & 194 & 24,16 & $\pm 1,34$ \\
\hline \multirow[t]{8}{*}{57.1748} & $\mathrm{KOH}$, acetolysis $\ldots \ldots \ldots \ldots$ & 0 & 24,59 & $\pm 1,85$ \\
\hline & & 56 & 24,28 & $\pm 1,39$ \\
\hline & & 112 & 23,46 & $\pm 1,07$ \\
\hline & & 182 & 23,33 & $\pm 1,06$ \\
\hline & $\mathrm{KOH}, \mathrm{HF}$, acetolysis . . . . . . & 1 & 24,02 & $\pm 1,40$ \\
\hline & & 55 & 24,13 & $\pm 1,31$ \\
\hline & & 111 & 23,83 & $\pm 1,32$ \\
\hline & & 189 & 23,75 & $\pm 1,24$ \\
\hline \multirow[t]{9}{*}{ ○ 1561} & $\mathrm{KOH}$, acetolysis $\ldots \ldots \ldots \ldots$ & 8 & 23,48 & $\pm 1,14$ \\
\hline & & 71 & 23,72 & $\pm 1,09$ \\
\hline & & 111 & 23,41 & $\pm 1,22$ \\
\hline & & 189 & 23,10 & $\pm 1,26$ \\
\hline & $\mathrm{KOH}, \mathrm{HF}$, acetolysis . . . . . . . & 8 & 22,69 & $\pm 1,27$ \\
\hline & & 73 & 23,17 & $\pm 1,17$ \\
\hline & & 114 & 22,74 & $\pm 1,10$ \\
\hline & & 189 & 22,50 & $\pm 1,26$ \\
\hline & & 372 & 22,38 & $\pm 1,17$ \\
\hline
\end{tabular}

Table 7. Significance tests for size changes according to table 6 .

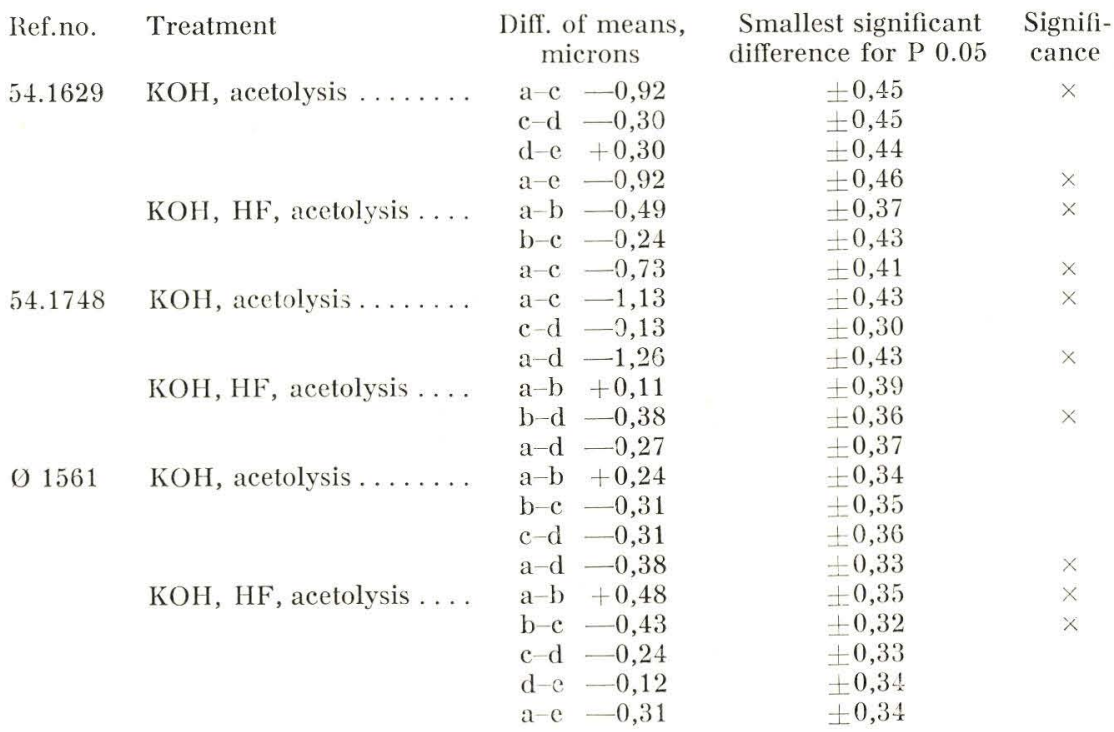


Table 8. Corylus avellana, modern (Hareskoven, N. Zealand, $\mathrm{KOH}$, acetolysis).

\begin{tabular}{|c|c|c|c|c|}
\hline Dehydrant & Solvent & Medium & $\begin{array}{c}\mathrm{M} \\
\text { microns }\end{array}$ & $\begin{array}{c}\sigma \\
\text { microns }\end{array}$ \\
\hline & & water ........... & 30,91 & $\pm 1,43$ \\
\hline & water ............. & glycerin . . . . . . . . & 33,02 & $\pm 1,74$ \\
\hline acetone & $\ldots \ldots \ldots \ldots \ldots \ldots$ & acetone .......... & 27,89 & $\pm 1,66$ \\
\hline- & acetone $\ldots \ldots \ldots \ldots$ & glycerin . . . . . . . & 33,30 & $\pm 1,85$ \\
\hline - & $\ldots \ldots \ldots \ldots$ & tricaproïn . . . . . . & 27,01 & $\pm 1,50$ \\
\hline - & benzene.......... & benzene........... & 26,56 & $\pm 1,34$ \\
\hline - & $\ldots \ldots \ldots \ldots$ & silicone oil. . . . . . . & 25,88 & $\pm 1,20$ \\
\hline alcohol & $\ldots \ldots \ldots \ldots \ldots \ldots$ & alcohol. . . . . . . . & 28,09 & $\pm 1,33$ \\
\hline- & alcohol. . . . . . . . & glycerin . . . . . . . . & 33,25 & $\pm 1,79$ \\
\hline- & $\ldots \ldots \ldots \ldots$ & methylen chloride ... & 29,02 & $\pm 1,76$ \\
\hline - & methylen chloride ... & silicone oil. . . . . . . & 26,65 & $\pm 1,44$ \\
\hline - & $\ldots \ldots \ldots \ldots$ & benzene. . . . . . . . . & 27,11 & $\pm 1,39$ \\
\hline - & benzene. . . . . . . . . & tricaproïn . . . . . . . & 27,29 & $\pm 1,39$ \\
\hline - & $-\quad \ldots \ldots \ldots$ & silicone oil . . . . . . & 25,64 & $\pm 1,52$ \\
\hline
\end{tabular}

